\title{
DINAMIKA WACANA \\ FORMALISASI SYARIAT DALAM POLITIK: Ikhtiar Menemukan Relevansi Relasi Agama dan Negara Perspektif Indonesia
}

\author{
Mahathir Muhammad lqbal \\ Lakpesdam PCNU Kota Malang \\ e-mail: iqbalz_mm@yahoo.com
}

\begin{abstract}
This research is an effort to find the relevance of the relationship between religion and the state are ideal. Because the formalization of Islamic shariah issue in political discourse is an interesting study in the relation between religion and state. By using the library approach, this article analyzes the involvement of the state in regulating citizens to implement Islamic shariah in Indonesia. Neutrality of the state to be the key in finding the relationship of both. Theoretically, this study provides an explanation that neutrality is not only understood as a state of devotion to give the rights of citizens to pray by faith, but also to limit citizens. For the implementation of shariah will be established and run well, when the state has a neutrality. So the state does not attract Islamic shariah becomes an official policy or state laws (shariah formalization). So also a Muslim can bring religion into the political circle, but only in the level of political ethics.
\end{abstract}

Penelitian ini merupakan ikhtiar untuk menemukan relevansi hubungan agama dan negara yang ideal. Sebab Isu formalisasi syariat Islam dalam politik menjadi kajian menarik dalam wacana relasi agama dan negara. Dengan menggunakan pendekatan pustaka, artikel ini menganalisis keterlibatan negara dalam mengatur warga negara untuk mengimplementasikan syariat Islam di Indonesia. Adanya netralitas negara menjadi kunci dalam menemukan relasi keduanya. Secara teoritis, studi ini memberikan penjelasan bahwa netralitas tidak hanya dipahami sebagai pengabdian negara untuk memberikan hak-hak warga negara untuk berdoa berdasarkan iman, tetapi juga untuk membatasi warga negara. Sebab dalam pelaksanaan syariat akan dapat mapan dan berjalan dengan baik, manakala negara memiliki netralitas. Sehingga negara tidak menarik syariat Islam menjadi sebuah kebijakan resmi atau peraturan negara (formalisasi syariat). Dengan begitu seorang Muslim dapat membawa agama ke dalam lingkaran politik, tetapi hanya dalam tingkat etika politik.

Keywords: formalisasi syariah, netralitas negara, etika politik 


\section{A. Pendahuluan}

Sebuah keprihatinan yang mendalam apabila kita mengamati perkembangan masyarakat kita sejak era reformasi pada 1998 yang lalu, khususnya bila kita lihat dari perspektif sistem nilai yang semakin porak-poranda. Keprihatinan itu akan semakin dalam bila kita kaitkan posisi Indonesia sebagai bangsa Muslim terbesar di muka bumi, tetapi yang agak rapuh dalam masalah etika dan moral. Menurut hasil sensus tahun 2010, 87,18\% dari 237.641.326 penduduk Indonesia adalah pemeluk Islam 6,96\% Protestan 2,9\% Katolik, 1, 69\% Hindu, 0,72\% Buddha, 0,05\% Kong $\mathrm{Hu} \mathrm{Cu}, 0,13 \%$ agama lainnya, dan 0,38\% tidak terjawab atau tidak ditanyakan. ${ }^{1}$ Angka-angka ini menunjukkan bahwa secara nominal kuantitatif, bangsa Indonesia di samping bangsa Muslim terbesar, juga dikenal sebagai bangsa yang religius. Hanya sebesar 0,38\% yang tidak dapat dikategorikan penganut agama tertentu, tetapi mereka punya kepercayaan sendiri pula. Dengan kata lain, pengikut ateisme susah sekali kita temukan di bumi Nusantara ini.

Indonesia hari ini sedang luka dan pedih oleh ulah para elit, pejabat publik, dan politisi. Mereka banyak terlibat dalam kasus-kasus korupsi, konflik kepentingan, dan kerapuhan birokrasi. Kita mungkin lelah, tetapi nasib Indonesia memang berada dalam jeratan praktik politik tanpa etika. ${ }^{2}$

Berdasarkan data Kementerian Dalam Negeri sejak 2005 hingga sekarang, jumlah bupati/wali kota/gubernur yang tersangkut korupsi mencapai 297 kepala daerah. Melihat terdapat kasus yang ditangani penyidik yang melibatkan kepala daerah, diprediksi angkanya bisa tembus 300 orang hingga akhir tahun ini. Hal yang sama juga menimpa legislatif, karena sekitar 2.500 anggota DPRD kabupaten/kota terseret kasus hukum. Dari jumlah itu, terdapat 1.050 orang (40, $07 \%$ teridentifikasi kasusnya adalah penyimpangan anggaran. Pelaksanaan pemilukada sejak 2004 yang sarat dengan ekonomi biaya tinggi berimbas pada meningkatnya aparatur negara yang berurusan kasus hukum. Hingga akhir 2012, sedikitnya 1.364 pegawai negeri sipil (PNS) yang terjerat korupsi, dengan status tersangka hingga terpidana. ${ }^{3}$

\footnotetext{
${ }^{1}$ http://id.wikipedia.org/wiki/Agama_di_Indonesia, diakses pada tanggal 20 Maret 2014.

2Bandung Mawardi, “Politik Beretika Publik,” Jawa Pos, 27 Juli 2011, h. 4.

3Erik Purnama Putra, "Ketika Semangat Otda Diselewengkan Kepala Daerah", http://www. republika.co.id/berita/nasional/umum/13/07/22/mqadir-ketika-semangat-otda-diselewengkankepala-daerah. Diakses pda tanggal 15 Maret 2014.
} 
Data berbeda tetapi dengan subtansi yang sama dilansir oleh Komisi Pemberantasan Korupsi, mencatat bahwa dalam rentang kurun 10 tahun terakhir, atau 2004-2013, ada 42 kepala daerah yang terjerat kasus hukum. Angka itu terdiri atas gubernur 8 orang, wali kota 10 orang, wakil wali kota 1 orang, bupati 22 orang, dan wakil bupati 1 orang. Sebarannya dari Aceh hingga Papua dengan 36 orang berstatus inkracht (berkekuatan hukum tetap), 1 kasasi, 4 tersangka, dan 1 dihentikan karena kesehatan terdakwa tidak memungkinkan. Wakil Ketua KPK Bidang Pencegahan Busyro Muqoddas menyatakan, data ini semakin membuat mata kita terbuka. ${ }^{4}$

Data terbaru, Kementerian Dalam Negeri mencatat hingga Januari 2014 sebanyak 318 orang dari total 524 orang kepala daerah dan wakil kepala daerah tersangkut dengan kasus korupsi. Untuk itu harus ada perbaikan dalam pemilihan kepala daerah (pilkada) yang diadakan pada 2015 atau setelah pelaksanaan pemilihan umum legislatif 9 April 2014 serta pemilihan presiden 9 Juli $2014 .{ }^{5}$

Dalam hal ekonomi, juga tak kalah mengenaskan. Meski Pemerintah Indonesia mengklaim bahwa kita telah mengalami pertumbuhan sebesar 8\%, tetapi realitas di lapangan telah menunjukkan sebaliknya. Kekayaan hanya milik segelintir orang tertentu. Ironi juga muncul bila melihat realitas orang miskin di Indonesia berjumlah sekitar 8 kali lipat penduduk Singapura, tetapi banyak orang berduit asal Indonesia yang membeli properti di Singapura. Bahkan, selama 2010 tercatat 2, 3 juta orang penduduk Indonesia mengunjungi Singapura hanya untuk berlibur. Sebaliknya, orang Singapura yang datang ke Indonesia dalam kurun waktu yang sama hanya belasan ribu orang. Pertumbuhan ekonomi yang eksklusif saat ini telah menjerumuskan sekian banyak penduduk Indonesia dalam jurang kemelaratan dan ketimpangan. Hanya sebagian kecil penduduk negeri ini yang menikmati tingginya pertumbuhan ekonomi. ${ }^{6}$

Belum lagi kita dilanda krisis moralitas. Moralitas yang dominan sekarang adalah moralitas hegemoni pasar yang ganas untuk memburu untung sebanyakbanyaknya tanpa hirau terhadap dampak buruk yang harus diderita sebagian besar umat manusia. Erich Fromm menggambarkan manusia modern itu sebagai

\footnotetext{
${ }^{4}$ Lihat dalam Harian Seputar Indonesia Edisi 2 Agustus 2013 h. 4.

5http://www.jpnn.com/read/2014/02/15/216728/318-Kepala-Daerah-Terjerat-Korupsi-, diakses pada tanggal 20 Maret 2014.

${ }^{6}$ Agus Suman, “Orang Kaya Versus Kemiskinan”, http://feb.ub.acid/agus-suman-orang-kayakemiskinan.html, diakses pada tanggal 16 Maret 2014.
} 
homo consumens dengan tujuan tunggal "to have more and to use more" (memiliki lebih banyak dan melahap lebih banyak).?

Umat Islam yang mayoritas di Indonesia itu termasuk mereka yang harus menderita dalam himpitan arus global, tetapi semua ini terjadi karena kesalahan langkah yang mereka lakukan pada abad-abad yang lalu hingga kendali peradaban terlepas dari genggaman mereka. Mereka seakan terkapar di pinggir jalan raya kehidupan yang hiruk pikuk oleh sorak-sorai manusia yang kehilangan makna. ${ }^{8}$

Harus diakui, cita-cita ideal sosial politik untuk konteks Indonesia saat ini memang masih utopis. Kebusukan dan kebohongan politik, konflik kepentingan serta lakon korupsi sudah begitu merata sehingga masyarakat tak tahu siapa lagi yang dapat dipercaya.

Politik kadang picik dan licik. Kita kerap menderita karena ulah politik para elit, pejabat publik, dan politisi mengingkari masa kekuasaan. Mereka tak melakoni politik dengan etika publik. Kekuasaan diraih dengan pengabaian hukum, etika, dan nilai-nilai kemanusiaan. Indonesia kentara mengalami defisit keluhuran dalam politik. Dalam skala yang lebih luas, fenomena ini telah menstimulus masyarakat untuk menggugat demokrasi. Pasalnya, dalam pandangan para penggugat itu, setelah lebih dari satu dekade proses demokratisasi kondisi Indonesia dianggap tak lebih baik. Di sejumlah hal terdapat paradoks antara yang satu dengan yang lain.

Demokrasi menjadi kambing hitam. Bagi mereka sistem demokrasi merupakan produk Barat sehingga harus ditolak. Solusi yang ditawarkan adalah kembali pada syariah dan khiläfah. Dengan penuh keyakinan mereka menyatakan bahwa segala persoalan di negeri ini akan selesai dengan syariah dan khiläfah. ${ }^{9}$ Hal ini dapat dipahami mengingat demokrasi itu bukanlah sesuatu yang statis, ia fluktuatif. Sebagai sebuah konstruksi mental, keyakinan terhadap demokrasi sama dengan naik-turunnya level keimanan kita. ${ }^{10}$ Dari latar belakang di atas, maka penulis tertarik untuk meneliti bagaimanakah dinamika wacana formalisasi syariat dalam politik perspektif Indonesia.

\footnotetext{
7Erich Fromm, The Revolution of Hope: Toward a Humanized Technology, (New York: Harper \& Row, 1968), h. 38.

${ }^{8}$ Ahmad Syafii Maarif, Indonesia di Simpang Jalan, (Bandung: Mizan, 1998), h. 182-183.

${ }^{9}$ Biyanto, "Imajinasi Politik Islam", Jawa Pos, 18 Maret 2014, h. 4.

${ }^{10}$ Samuel Huntington, The Third Wave: Democratization in the Late Twentieth Century, (Norman: University of Oklahoma Press, 1991), h. 17.
} 
Berdasarkan uraian latar belakang di atas, maka dalam tulisan ini akan mengurai dinamika wacana formalisasi syariat dalam politik perspektif Indonesia. Dengan melihat hal itu, maka kita akan semakin terang tentang relasi agama dan negara yang ideal perspektif Indonesia. Kajian yang akan dilakukan ini sebagai langkah untuk mendeskripsikan, menganalisis dan menginterpretasikan, terlebih mengenai dinamika wacana formalisasi syariat dalam politik perspektif Indonesia. Bahkan akan menemukan relevansi relasi agama dan negara yang ideal perspektif Indonesia.

Hasil penulisan ini diharapkan dapat memberi manfaat bagi pembaca. Sebab dalam tulisan ini, ingin mendalami dan mengetahui dinamika wacana dan isu formalisasi syariat dalam perspektif Indonesia. Tidak hanya itu saja, pembaca akan dapat memahami dan merumuskan sebuah konsep yang relevan hubungan antara agama dan negara dalam perspektif Indonesia.

Penelitian ini menggunakan pendekatan deskriptif kualitatif, dan jenis penulisan yang digunakan adalah kepustakaan atau library research yaitu mengumpulkan data atau karya tulis ilmiah yang bertujuan dengan objek penelitian atau pengumpulan data yang bersifat kepustakaan. Atau telaah yang dilaksanakan untuk memecahkan suatu masalah yang pada dasarnya bertumpu pada penelaahan kritis dan mendalam terhadap bahan-bahan pustaka yang relevan. Sumber data penelitian ini meliputi sumber data primer yaitu hasil-hasil penelitian atau tulisan-tulisan karya peneliti atau teoritisi yang orisinil dan sumber data sekunder adalah bahan pustaka yang ditulis dan dipublikasikan oleh seorang penulis yang tidak secara langsung melakukan pengamatan atau berpartisipasi dalam kenyataan yang ia deskripsikan. Dengan kata lain, penulis tersebut bukan penemu teori. Sumber data sekunder yang menjadi pendukung adalah buku, artikel, dokumen, laporan-laporan dan sumber lainnya yang mempunyai relevansi dengan objek.

Adapun teknik pengumpulan data yang digunakan adalah pengumpulan data literer, yaitu bahan-bahan pustaka yang koheren dengan objek pembahasan yang dimaksud. Analisis data dalam kajian pustaka (library research) ini adalah analisi isi (content analysis), yaitu penelitian yang bersifat pembahasan mendalam terhadap isi suatu informasi tertulis atau tercetak dalam media massa, untuk membuat inferensi-inferensi yang dapat ditiru (replicable) dan sahih data dengan memperhatikan konteksnya. 


\section{B. Syariah dan Politik; Sebuah Kajian Historis}

Sebagai agama, Islam terdiri dari keyakinan atau iman dan rasa memiliki, dan dalam praktiknya kedua unsur tersebut saling memiliki. Dalam interaksi ini, kehidupan sosial dan politik umat Islam didefinisikan secara berbeda-beda di kalangan kaum Muslim itu sendiri. Dalam hubungan itu, penafsiran atas konsep syariah sangat krusial. ${ }^{11}$ Syariah berarti "jalan menuju air, yakni jalan menuju sumber kehidupan. ${ }^{12}$ Dalam konteks ini sumber kehidupan adalah Allah sendiri. lebih lanjut, Rahman berbicara secara lebih teknis lagi tentang syariah sebagai:

"nilai-nilai agama, yang diungkapkan secara fungsional dan dalam istilahistilah yang nyata, untuk mengarahkan kehidupan manusia... jalan, yang telah ditentukan oleh Allah di mana manusia harus menjalani hidup dengan mewujudkan kehendak Allah.... syariah mencakup semua perilaku, spiritual, mental, dan psikis. Dengan demikian ia mencakup iman dan amal. ${ }^{13}$

Definisi syariah tersebut sesuai dengan pendekatan terhadap agama sebagai interaksi antara iman dan rasa memiliki atau rasa menganut. Namun demikian, terdapat perbedaan yang tajam di kalangan para sarjana Muslim mengenai makna dan cakupan syariah. Secara umum, umat Islam percaya bahwa sumber pertama syariah adalah al-Qur'an. Persoalan yang muncul kemudian terkait dengan cakupan al-Qur'an: apakah ia mencakup semua persoalan hukum yang berkaitan dengan perilaku umat Islam dalam sebuah masyarakat yang berubah. Rahman berpendapat bahwa "bagian yang tegas dalam hukum al-Qur'an jumlahnya sangat kecil”, ${ }^{14}$ dan karenanya tidak cukup untuk mengatur perilaku umat Islam. Muhammad Sa'id al-Asymawi, ketua Pengadilan Tinggi Mesir, menyatakan secara lebih spesifik tentang syariah sebagai berikut:

"Kata syariah muncul hanya sekali dalam al-Qur'an ... (QS al-Jasiyah [45]: 18), tetapi dalam al-Qur'an orang menjumpai tiga kata lain yang berasal dari akar kata yang sama (QS al-Ma'idah [5]: 48; QS Fushilat [42]: 13 dan 41). Di semua ayata tersebut, syariah tidak menunjuk pada norma hukum, tetapi pada jalan". ${ }^{15}$

\footnotetext{
${ }^{11}$ Saiful Mujani, Muslim Demokrat: Islam, Budaya Demokrasi, dan Partisipasi Politik di Indonesia Pasca Orde Baru, (Jakarta: Gramedia Pustaka Utama, 2007), h. 52.

${ }^{12}$ Fazlur Rahman, Islam, (Chicago, University of Chicago Press, 1979), h. 100.

13Fazlur Rahman, Islam, h. 100-101.

${ }^{14}$ Fazlur Rahman, Islam, h. 68.

${ }^{15}$ Muhammad Sa'id al-Asymawi, Shari'a: The Codification of Islamic law", (Oxford: Oxford University Press, 1998), h. 50.
} 
Sifat al-Qur'an yang tidak banyak berbicara tentang hukum secara rinci kemudian ditanggulangi dengan cara memasukkan Sunnah sebagaiman dipelihara dalam Hadits, yakni berita-berita tentang kehidupan Nabi Muhammad SAW dalam masyarakat, sebagai sumber syariah. Dengan kata lain, hadits diyakini sebagai sumber kedua syariah. Ia mencakup muatan yang lebih luas tentang interaksi sosial dan politik dalam masyarakat Muslim. Posisi penting sunnah sebagai sumber kedua syariah, menurut Rahman dilegitimasikan sejak Nabi meninggal dunia dengan doktrin 'ismah Nabi, yakni ketidakmungkinan Nabi berbuat salah. ${ }^{16}$

Setelah Nabi wafat dan masyarakat Muslim berkembang lebih luas, malampaui Jazirah Arab, sunnah itu sendiri dirasakan tidak cukup untuk mengatur perilaku kaum Muslim. Sebuah kontroversi lalu muncul. Sekelompok sarjana yang dikenal dengan ahl al-hadith mengklaim bahwa Islam yang benar atau syariah yang dimanifestasikan dalam jama'ah harus mengikuti "Sunnah Jama'ah", yakni komunitas Muslim di bawah kepemimpinan Nabi di Madinah. Pengaruh apapun dari luar sunnah jama'ah dianggap sebagai penyimpangan dari model tersebut dan tidak dapat ditolerir.

Kelompok ulama lain memberikan argumen yang berlawanan. Mereka berpendapat, benar bahwa sunnah tidak pernah salah dalam konteks historisnya. Namun, ketika konteks tersebut berubah, seperti biasa terjadi dalam masyarakat manapun, sunnah tidak lagi cukup untuk membimbing perilaku umat Islam. Perubahan sosial tersebut membuka peran personal bagi para ulama untuk menafsirkan al-Qur'an dan Hadits. Pendapat pribadi ini (fiqh) terbuka terhadap kemungkinan salah. Kelompok ahl al-hadith tidak dapat menerima argumen ini dan selalu menekankan Islam jama'ah sebagai model yang benar bagi masyarakat Muslim tanpa harus mempertimbangkan perubahan sejarah umat Islam.

Kedua keyakinan yang berbeda tentang sifat dasar syariah di atas mempengaruhi cara bagaimana para ulama dan aktivis Muslim kontemporer membayangkan masyarakat Muslim, termasuk persepsi mereka tentang hubungan agama dan politik.

Dalam kajian historis ${ }^{17}$, perdebatan antara Islam di Indonesia akan diterapkan secara formal atau kultural telah muncul sejak persiapan kemerdekaan

16Fazlur Rahman, Islam, h. 68.

17Lily Zakiyah Munir, “FormalisasiSyariat dan Komitmen Kebangsaan”, Jawa Pos, 29 Agustus 2003, h. 31. 
negeri tercinta ini. Sejarah mencatat perdebatan seru antara dua kelompok Islam dalam Badan Penyelidik Usaha-usaha Persiapan Kemerdekaan Indonesia (BPUPKI). Kelompok pro syariat formal berpendapat bahwa logis bila Islam diformalkan karena mayoritas penduduk Indonesia adalah Muslim. Sementara kelompok kultural berdalih bahwa Islam akan mencerminkan misi ra hmatan li q'ālamin dengan pendekatan kultural seperti yang selama ini berkembang di Indonesia. Kedua kelompok, menariknya berangkat dari ayat yang sama. Yaitu "wa man lam yahkum bimā anzalallāh faulāika humu 'l-käfirūn" (dan barang siapa yang tidak menegakkan hukum sesuai dengan perintah Allah, maka mereka adalah kafir). Perbedaan penafsiran ayat itu menyebabkan adanya dikotomi formal maupun kultural hingga kini.

Dikotomi ini tidak lepas dari pengaruh politik identitas Islam secara global. Jelaslah bahwa semangat perjuangan dan ketulusan para penganjur gerakan Islam internasional tidak perlu diragukan. Jamaluddin al-Afghani dan muridnya Muhammad 'Abduh berjuang menghantam kolonialisme Barat, sementara itu juga mengkritisi kelemahan masyarakat Muslim sendiri.

Di pengungsiannya di Paris, 'Abduh mengatakan bahwa dia menemukan nilai-nilai islami (seperti kebebasan berpendapat) dipraktikkan di sana. Sementara Hassan al-Banna dari Mesir memerangi kebobrokan moral pemerintah yang diwariskan oleh Muhammad 'Ali Pasya. Perkembangan gerakan tersebut mulai terdistorsi perlahan-lahan karena minimnya cakrawala berpikir keulamaan para penerus mereka.

Gerakan modernis yang menginginkan formalisasi syariat dan menggeser nilai-nilai kebangsaan ini semakin melambung setelah Revolusi Iran pada 1979. Beberapa negara Timur Tengah seperti Arab Saudi memiliki kepentingan untuk membendung pengaruh Ayatullah Khomeini yang bersumpah akan mengekspor revolusinya ke seluruh dunia. Maka digerakkan rekayasa politik guna mempersatukan Islam dengan menghancurkan wacana kebangsaan. Gerakan ini sebetulnya ingin memberikan perlawanan terhadap Iran.

Kalau Iran memunculkan Syi'ah sebagai basis ideologisnya, gerakan ini menggunakan wacana Salafi atau Sunni. Dari sini muncul orang seperti Abu alA'la al-Maududi dari Pakistan dengan Jami'ati Islami, yang kemudian berkolaborasi dengan Rabithah 'Alam al-Islam yang didukung Arab Saudi. Gerakan internasional inilah yang sangat berpengaruh terhadap upaya penghapusan identitas kebangsaan di Indonesia. 


\section{Dinamika Wacana Formalisasi Syariat dalam Politik Perspektif Indonesia}

Di kalangan umat Islam sampai sekarang terdapat tiga aliran tentang hubungan antara Islam dan negara. Aliran pertama berpendirian bahwa Islam bukanlah semata-mata agama dalam pengertian Barat, yakni hanya menyangkut hubungan manusia dengan Tuhan, sebaliknya Islam adalah satu agama yang sempurna dan yang lengkap dengan pengaturan bagi segala aspek kehidupan manusia termasuk kehidupan bernegara. Para penganut aliran ini pada umumnya berpendirian bahwa: 1) Islam adalah suatu agama yang serba lengkap. Di dalamnya terdapat pula antara lain sistem ketatanegaraan atau politik. Oleh karenanya dalam bernegara umat Islam hendaknya kembali kepada sistem ketatanegaraan Islam, dan tidak perlu atau bahkan jangan meniru sistem ketatanegaraan Barat; 2) Sistem ketatanegaraan atau politik islami yang harus diteladani adalah sistem yang telah dilaksanakan oleh Nabi Muhammad SAW dan oleh empat al-Khulafä' al-Rāshidīn. Tokoh-tokoh utama dari aliran ini antara lain Syekh Hassan al-Banna, Sayyid Quthb, Syekh Muhammad Rasyid Ridha, dan yang paling vokal adalah Maulana Abu al-A'la al-Maududi.

Aliran kedua berpendapat bahwa Islam adalah agama dalam pengertian Barat, yang tidak ada hubungannya kenegaraan. Menurut aliran ini Nabi Muhammad hanyalah seorang rasul biasa seperti halnya rasul-rasul sebelumnya, dengan tugas tunggal mengajak manusia kembali kepada kehidupan yang mulia dengan menjunjung tinggi budi pekerti luhur, dan Nabi tidak pernah dimaksudkan untuk mendirikan dan mengepalai suatu negara. Tokoh-tokoh terkemuka dari aliran ini antara lain adalah 'Ali ‘Abd al-Raziq dan Dr. Thaha Husein.

Aliran ketiga menolak pendapat bahwa Islam adalah suatu agama yang serba lengkap dan bahwa dalam Islam terdapat sistem ketatanegaraan. Tetapi aliran ini juga menolak anggapan bahwa Islam adalah agama dalam pengertian Barat yang hanya mengatur hubungan antara manusia dan Maha Penciptanya. Aliran ini berpendirian bahwa dalam Islam tidak terdapat sistem ketatanegaraan, tetapi terdapat seperangkat tata nilai etika bagi kehidupan bernegara. Di antara tokohtokoh dari aliran ketiga ini yang terhitung cukup menonjol adalah Dr. Muhammad Husain Haikal, seorang penulis Islam yang cukup terkenal dan penulis buku Hayatu Muhammad dan Fi Manzil al-Wahyi. ${ }^{18}$

\footnotetext{
18Munawir Syadzali, Islam dan Tata Negara: Ajaran, Sejarah, dan Pemikiran, Oakarta: UI Press, 1993), h. 1-2.
} 
Bagi golongan aliran pertama, sistem demokrasi adalah sebuah sistem yang harus ditolak karena berasal dari Barat. Selain itu, kelompok aliran pertama juga beranggapan bahwa kekuasaan yang sebenarnya adalah kekuasaan Tuhan. Solusi yang ditawarkan adalah kembali pada syariah dan khilāfah. Dengan penuh keyakinan mereka menyatakan bahwa segala persoalan di negeri ini akan selesai dengan formalisasi syariah dalam naungan sistem politik khilāfah.

Karena itu konsep demokrasi mereka tolak karena melandaskan kekuasaan pada kemauan rakyat. ${ }^{19}$ Islamisasi bagi kelompok aliran pertama ini adalah agenda yang terus hidup (the living agenda). Itulah yang menjadi alasan utama isu formalisasi syariat Islam tak pernah ditinggalkan. Tapi ada beberapa kelemahan yang tidak disadari oleh pengusung aliran pertama ini yakni: Pertama, kalau kita kembali mempelajari sejarah, sesungguhnya akan kita temukan bahwa sebenarnya Nabi tak pernah menetapkan satu bentuk kekuasaan politik tertentu. Hal ini dapat dilihat dalam proses pengangkatan keempat khalifah, yang semuanya terkesan ad hoc serta tidak ada model yang secara konsisten diikuti dari waktu ke waktu. Abu Bakar diangkat secara aklamasi; Umar diangkat melalui wasiat; Utsman diangkat melalui tim formatur yang diprakarsai Umar; dan 'Ali diangkat melalui aklamasi. Dalam sebuah diskusi, Abdullahi Ahmad An-Naim, intelektual asal Sudan, dengan nada emosi bertanya kepada para hadirin agar menunjukkan mana yang disebut sistem khilāfah: aklamasi, wasiat, atau formatur. Sama sekali tidak ada. Ini menunjukkan bahwa urusan politik dalam Islam adalah urusan dunia.

Setelah periode Sahabat, terjadi perubahan yang sangat mendasar dalam sistem kekuasaan. Bani Umayyah dan Bani Abbas mengembangkan sistem dinasti, di mana kekuasaan diwariskan menurut garis keluarga. Tradisi yang dikembangkan oleh generasi Sahabat sama sekali ditinggalkan. Hal ini menunjukkan tidak ada bukti sedikitpun dalam sejarah Islam di mana sistem "khiläfah"kalau bisa disebut demikian — dibangun secara konsisten dan konsekuen.

Sejarah menunjukkan bahwa dalam Islam bentuk-bentuk kekuasaan berubah dari masa ke masa. Generasi Sahabat mengembangkan cara-cara yang berbeda dengan generasi Tabi'in, dan seterusnya. Bentuk-bentuk kekuasaan berubah sesuai dengan kondisi dan situasi. Tidak ada satu bentuk kekuasaan lebih 'islami' dari bentuk lainnya dalam pengertian bahwa bentuk kekuasaan

${ }^{19}$ Husein Muhammad, "Hukum Tuhan Tetap Perlu Tafsir Manusiawi”, Jawa Pos, 30 Mei 2004, h. 4. 
tertentu berasal dan sesuai dengan Islam sementara lainnya tidak. Ini disebabkan kenyataan bahwa sejak awal Islam tak memperkenalkan satu bentuk kekuasaan pun. Islam hanya menekankan pentingnya moral dalam kekuasaan.

Anehnya periode dinasti Islam, terutama dinasti Umayyah dan Abbasiyyah, yang berhasil membangun peradaban Islam sebagai peradaban dunia, seringkali dirujuk oleh para pendukung sistem khiläfah sebagai puncak dari sistem khiläfah Islam. Pada jaman dinasti Islam, kekuasaan sudah banyak berubah dan terkadang menjadi despotisme yang jelas-jelas bertentangan dengan moral agama. Para khaliffah naik ke panggung kekuasaan dengan cara-cara yang tidak terpuji dan bahkan bertentangan dengan nilai-nilai agama. Puncak dari despotisme adalah ketika khaliffah mengklaim diri mereka sebagai bayang-bayang Tuhan di muka bumi.

Inilah ironi ketika sekelompok orang menganggap konsep khilāfah, yang tidak jelas dan telah bercampur baur dengan despotisme, sebagai bagian yang paling inheren dari agama dan konsep tersebut dipercaya sebagai konsep kekuasaan yang diperkenalkan Nabi pada para Sahabatnya. Tugas umat menurut mereka- adalah mengembalikan kekuatan umat yang tercerai berai ini ke dalam sistem khilāfah.

Pandangan seperti ini jelas tak bisa diterima karena menyelewengkan realitas sejarah. Konsep khiläfah muncul sebagai akibat dari ketidakmampuan umat Islam dalam menghadapi persaingan dunia saat ini. Dalam ketidakmampuannya, sebagian umat melakukan refleksi. Namun refleksi ini tidak dibarengi dengan kritisisme yang tinggi. Sejarah dilihat dengan penuh kekaguman. Dalam keadaan seperti itu orang tidak dapat membedakan mana kenyataan dan mana mimpi. Muncullah sikap romantisme yang memandang masa lalu dengan penuh perasaan yang menggelora.

Khiläfah adalah semacam romantisme karena memimpikan Islam bangkit kembali sebagai peradaban dunia. Mimpi tentang 'kejayaan Islam' sebenarnya sah-sah saja sepanjang didasarkan pada realitas sejarah. Sejarah mengajarkan bahwa kejayaan Islam pada masa lalu tidak disebabkan oleh satu sistem politik tertentu saja, sebab kenyataannya Islam — tepatnya sejarah Islam - tak mewariskan sistem politik dan kekuasaan yang tunggal. ${ }^{20}$

${ }^{20} J a j a n g$ Jahroni, “Khilafah Islam: Khilafah yang Mana?” Jawa Pos, 16 Mei 2004, h. 4. 
Kedua, masih berkaitan dengan sejarah, berdasar tulisan Rasul Jafariyan yang membaca "Sejarah Khilafah 11-35 H", ternyata model khiläfah juga bukan sesuatu yang sangat ideal dan menampakkan substansi keislaman yang nyata. ${ }^{21}$

Di bagian belakang buku itu digambarkan, "belakangan ini banyak Muslim yang mendambakan khiläfah menjadi sistem pemerintahan. Benarkah khiläfah adalah sistem pemerintahan Islam yang patut dilanjutkan? Ataukah ia adalah alat kekuasaan sekelompok orang yang secara lancing memanipulasi jargon agama? Sebelum mendambakan atau menolaknya, Anda perlu tahu sejarah khiläfah." Ungkapan itu menggambarkan betapa saratnya kekhilafahan dengan perpolitikan, kepentingan, dan penguasaan yang sangat profan. Pendapat ini tentu tidak jauh berbeda dengan ungkapan Muhammad Said al-Asmawy yang menyatakan bahwa pertarungan yang terjadi dalam sejarah panjang umat Islam hanyalah menjadikan Islam sebagai kedok. Sedangkan isi atau tujuan sesungguhnya tak lain adalah kekuasaan.

Jika dibaca secara kritis, kekhilafahan pada masa al-khulafä' al-rāshidīn pun sudah memiliki nuansa kekuasaan politik yang sangat kental. Belum lagi peralihan-peralihan kekuasaan pada masa Abbasiyah dan Muawiyah. Kekhalifahan tersebut ternyata tidak ada bedanya dengan perubahan kekuasaan politik di tempat lain.

Sering dalam perubahan kekuasaan politik terkait dengan air mata. Jika demikian halnya, prototipe sistem pemerintahan ideal yang sesuai dengan ajaran mendasar Islam lalu sulit ditemui dalam realita empiris pasca masa kenabian Muhammad SAW. Dengan demikian, pertanyaan ontologis adakah sistem kekhilafahan yang ideal dan menjadi realitas empiris pasca-Nabi Muhammad SAW dan al-khulafä' al-rāshidīn ternyata agak sulit ditemukan? Makanya, gagasan tentang khiläfah sebagai solusi atas persoalan negara-bangsa, khususnya Indonesia, adalah pikiran tekstual, bukan kontekstual.

Selain itu, peralihan sistem pemerintahan historis Islam, dari khiläfah menuju dawlah (dinasti) agaknya juga penting dikaji lebih lanjut. Mengapa sistem pemerintahan "demokratis" al-khulafä' al-rāshidūn berumur sangat pendek (sekitar 30 tahun saja, termasuk 5 bulan pemerintahan sementara Hasan bin 'Ali), sementara sistem dinasti bertahan enam abad lebih 24 tahun? Dinasti Umayyah bertahan sepanjang 89 tahun, sejak Muawiyah (661 M) sampai Marwan II (750

\footnotetext{
${ }^{21}$ Nur Syam, "Implementasi Syariat Tanpa Institusi Formal,Jawa Pos, 16 Agustus 2007, h. 4.
} 
M). adapun Dinasti Abbasiyah lebih panjang umur, dan bertahan bertahan selama 535 tahun, sejak Abul Abbas al-Shaffah (750 M) sampai al-Mu'tashim $(1258 \mathrm{M}) .^{22}$

Menjawab persolaan di atas, Abied al-Jabiri mengajukan hipotesis bahwa model pemerintahan demokratis empat khalifah yang diadopsi dari praktek kepemimpinan Nabi di Madinah, sesungguhnya tidak selaras dengan zamannya. Secara sosiologis, kepemimpinan demokratis Nabi hanya aplikatif bagi masyarakat Mekah dan Madinah. Komunitas dua wilayah dikenal menggunakan sistem kabilah dan rekrutmen pemimpinnya atas dasar adagium primus interpares. Artinya, hanya individu yang terbaik dan paling cakap yang akan dipilih oleh komunitas tersebut. Begitu wilayah Islam mengembang ke Damaskus, Persia, Irak dan Mesir, pada zaman empat khalifah, sistem demokrasi menjadi tidak efektif lagi, karena mereka terbiasa dengan sistem kerajaan decisive (tegas) sebagaimana praktek Kerajaan Persia (seorang raja sekaligus merangkap sebagai pemimpin agama) dan kerajaan Romawi Timur (kekuasaan raja tunduk di pada kekuasaan gereja). ${ }^{23}$

Pemerintahan demokratis empat khalifah, nyatanya hanya berjalan normal dan aman pada dua periode setengah saja (masa Abu Bakar, Umar, dan permulaan masa Utsman), karena fakta bahwa khaliffah pertama dan kedua adalah sosok yang decisive ruler. Abu Bakar berani mengambil kebijakan tidak poluler dengan memaklumatkan perang terhadap kaum murtad, sementara Umar adalah sosok pemberani dan tegas. Pasca kedua figus tersebut, demokrasi berjalan abnormal, bahkan memunculkan the big chaos (al-fitnah al-kubrā) karena khalifahnya dikenal tidak decisive. Pada sisi inilah, tesis Robert N. Bellah yang mengatakan bahwa kepemimpinan demokratis Nabi di Madinah terlalu maju (too modern) untuk zamannya, dan karena itu dia berumur pendek, patut kita apresiasi lebih lanjut.

Segi-segi modernitas Madinah itu adalah tingkat komitmen yang tinggi, keterlibatan dan partisipasi dari seluruh jajaran masyarakat, dan keterbukaan posisi kepemimpinan terhadap ukuran kecakapan pribadi.24

Dalam sejarah tercatat, setelah sukses membohongi 'Ali dalam sidang tahkim, Muawiyah membuat keputusan yang aneh. Dia meninggalkan Madinah menuju Damaskus, meninggalkan tradisi khiläfah —-walaupun dia ditentang oleh

${ }^{22}$ Muhammad Sholehuddin, “Desakralisasi Politik Islam”, Jawa Pos, 8 Agustus 2004, h. 4.

${ }^{23} \mathrm{Abid}$ Al Jabiri, “Al-Aqlus Siyāsil 'Arabï”Vol. III, 1992, h. 231.

${ }^{24}$ Nurcholish Madjid, "Asas-Asas Pluralisme dan Toleransi Dalam Masyarakat Madani, dalam Abuddin Nata, dkk (ed), Problematika Politik Islam di Indonesia, (Jakarta: UIN Jakarta Press, 2002), h. 3. 
beberapa sahabat Nabi- dan menggantikannya dengan sistem Kerajaan Persia yang disebut sistem 'ajam (non-Arab) oleh Abied al-Jabiri. Sejarah menunjukkan, Dawlah Umawiyah, hasil kreasi politik dan ketegasan Mua'wiyah, ternyata mampu menanggulangi situasi chaos, dan diterima oleh kaum Sunni sebagai realitas politik yang dikukuhkan dalam istilah 'ām al-jamā'ah (tahun rekonsiliasi). Kreasi politik Muawiyah akhirnya menjadi pilihan utama para penguasa Islam klasik selanjutnya, sampai kita menapaki era modern.

Fakta sejarah di atas menunjukkan, bentuk negara menurut Islam sangat terbuka, asalkan mampu mengaktualisasikan maqāṣid al-sharīah. Republik Mesir, Kerajaan Arab Saudi, Kerajaan Konstitusional Malaysia, dan Demokrasi Indonesia adalah varian-varian negara Islam modern. Kebebasan beragama, toleransi, anti-diskriminasi, penegakan hukum, keadilan dan HAM adalah partikular dari maqāṣid al-sharīah yang wajib dikampanyekan para capres-cawapres, dan diaktualisasikan ketika mereka benar-benar terpilih. Jika itu tidak mereka kerjakan, maka sesungguhnya secara substansial mereka tidak layak disebut memimpin dengan nilai-nilai Islam.

Ketiga, Dengan mencitakan dunia Islam dipimpin seorang khaliffah, berarti tidak ada tempat bagi gagasan nasionalisme. Sebab, nasionalisme lebih menekankan pada kesamaan tujuan dalam kehidupan bernegara. Gagasan nasionalisme jelas mengakui eksistensi keragaman budaya, etnik, agama, dan bahasa, sebagai entitas yang memiliki tujuan untuk mewujudkan kebaikan bersama. Sementara, gerakan Islam politik membangun cita-cita berdasar kesamaan agama sehingga mengabaikan batas negara-bangsa (nation state).

Hal itu berarti gagasan mewujudkan negara Islam dapat dikatakan tidak memiliki dasar yang kuat, baik dalam tataran normatif maupun historis. Bahkan, dalam konteks kekinian cita-cita mendirikan negara Islam sebagai negara ideologis dapat dikatakan tidak kompatibel dengan dunia modern. Apalagi, realitas menunjukkan bahwa cita-cita membangun sistem politik yang bercorak transnasional selalu mengalami kegagalan. Cita-cita gerakan Islam politik di banyak negara juga belum berhasil diwujudkan.

Upaya membangun formalisasi syariat dalam konteks Indonesia yang mempunyai latar belakang sosial budaya yang heterogen semacam ini dipastikan tidak akan pernah tercapai. Seperti kata Buya Syafii Maarif, jika upaya serba radikal ini gagal, dan memang tidak punya syarat untuk berhasil, maka sebab utamanya adalah karena sebuah gagasan besar dikerjakan oleh otak-otak kecil 
yang lebih banyak dikuasai oleh emosi, bukan oleh kekuatan penalaran yang mantap secara teori. ${ }^{25}$

Karena itulah, Oliver Roy (1994) menyebut bahwa cita-cita gerakan Islam politik sebagai Islamic political imagination (imajinasi politik Islam). Pernyataan ini relevan dengan realitas politik di dunia Islam. Kondisi politik Indonesia juga menunjukkan gejala yang sama. Elite partai berasas Islam yang tergabung dalam PKS, PPP, dan PBB juga belum menunjukkan diri sebagai figur yang berintegritas. Demikian juga elite partai berbasis ormas keislaman seperti PKB dan PAN. Yang terjadi justru sebaliknya. Sebagian elite partai tersebut terjerat dalam kasus korupsi dan perempuan.

Dampaknya, partai Islam dan partai berbasis ormas keislaman selalu gagal menjadi partai besar. Itu dapat dilihat dari hasil pemilu sejak era reformasi. Hasil survei beberapa lembaga juga memprediksi bahwa nasib partai Islam dan partai berbasis ormas keislaman tidak akan membaik dalam Pemilu 2014. Justru partai berideologi nasionalis yang akan berjaya.

Realitas politik tersebut jelas tidak sejalan dengan data statistika yang menunjukkan jumlah umat Islam yang mayoritas. Karena itu, harus diakui bahwa politik aliran di negeri ini benar-benar telah tamat. Pilihan politik umat kian mencair dan otonom, tidak lagi terkotak-kotak berdasar perbedaan budaya, etnik, dan agama.

Yang menarik, terlepas dari benar tidaknya bahwa muara semua program Islamisasi tersebut adalah negara Islam, yang jelas, hampir seluruh sektor kehidupan publik di Indonesia kini mengalami sentuhan Islamisasi. Sayangnya, semua itu masih bersifat simbolis. Ornamental, dan di atas permukaan belaka. Perilaku sehari-hari sebagian besar penduduk negeri ini, tampaknya, masih jauh dari mencerminkan nilai-nilai Islam yang sejati.

Akhirnya, dapat dikatakan bahwa daya hidup isu dan wacana formalisme syariat dalam konteks Indonesia adalah isu dan wacana yang sia-sia. Hal ini dikarenakan selain isu formalisme syariat itu tidak mempunyai landasan sosio historis, kultural, serta teori yang ber-nas, yang perlu dicatat ialah hal ini juga disebabkan organisasi-organisasi besar Islam tidak ada yang tertarik pada gagasan itu. Misalnya Nahdlatul Ulama (NU), Muhammadiyah, Perti, atau Al-Irsyad.

\footnotetext{
${ }^{25}$ Ahmad Syafii Maarif, Titik-titik Kisar di Perjalananku: Autobiografi Ahmad Syafii Maarif,(Bandung: Mizan, 2009), h. 198.
} 
Padahal, bisa dikatakan bahwa mereka yang menguasai paling banyak massa Islam yang riil. ${ }^{26}$

Kelompok-kelompok yang mempunyai gagasan formalisme syariat itu berada di luar mainstream besar tersebut. Oleh karena itu, pendukung mereka kecil sekali. Tidak signifikan.

\section{Relasi Agama dan Negara yang Ideal Perspektif Indonesia}

Pada dasarnya, tanpa keterlibatan negara yang mendesak warga negara untuk menjalankannya, syariat Islam sesungguhnya justru bisa dijalankan dan bahkan memiliki masa depan lebih cerah. Hanya saja, peluang bagi masa depan pembumian syariah tersebut jadi mungkin diwujudkan dengan terlebih dulu melampaui setidaknya dua ilusi yang selama ini dipelihara seputar hubungan Islam dengan negara. Pertama, ilusi tentang negara Islam yang diandaikan bisa menjalankan prinsip-prinsip syariat melalui kekuatan negara yang memaksa. Kedua, ilusi yang tak kalah berbahayanya tentang keharusan Islam disepak jauhjauh dari kehidupan publik. ${ }^{27}$

Di titik inilah maka netralitas negara atas semua agama adalah sebuah keniscayaan. Netralitas yang tidak boleh dimaknai sebagai pengabaian negara atas hak-hak warga negara untuk melaksanakan agamanya, apalagi menghalanghalanginya. Sebab pelaksanaan syariat hanya mungkin terwujud sebaik-baiknya justru sepanjang negara bersikap netral terhadap syariat dan tidak memaksakannya menjelma kebijakan resmi atau perundang-undangan negara (formalisasi syariat). Karena itu, sembari menegaskan pentingnya pemisahan Islam dan negara, dalam waktu yang sama kita pun harus menekankan keniscayaan merawat baik-baik keterikatan antara Islam dengan politik.

Karena itulah harus ada perubahan cara pandang yang keliru tentang sekularisme yang oleh sebagian kaum Muslim selalu dicurigai akan mengasingkan dan memenjarakan Islam sepenuhnya menjadi urusan privat yang haram memasuki ruang publik. Padahal, penyempitan makna sekularisme melulu sebagai pemisahan agama dan negara selain tak realistis dan menyesatkan, hal ini juga berisiko pada kegagalan dalam memenuhi tuntutan kolektif kebijakan publik.

\footnotetext{
${ }^{26}$ Azyumardi Azra, Islam Substantif: Agar Umat tidakJadi Buih, (Bandung: Mizan, 2000), h. 196.

${ }^{27}$ Abdullah Ahmed al-Naim, Islam dan Negara Sekuler: Menegosiasikan Masa Depan Syariah, (Bandung: Mizan, 2007), h. 21.
} 
Dengan demikian, selain dimaksudkan untuk merehabilitasi konsep sekularisme yang kerap disalahtafsirkan, pemaknaan sekularisme sebagai pemisahan Islam dan negara tapi dengan tetap meniscayakan berkelindannya politik dengan Islam (deprivatisasi agama), sesungguhnya membuka peluang penerapan prinsip-prinsip syariah dalam kebijakan dan perundang-undangan resmi dengan tetap tunduk pada perisai-perisai hukum.

Sekularisme tersebut pada gilirannya juga memungkinkan negara berperan sebagai mediator guna memfasilitasi pelbagai perbedaan penafsiran agama. Dan karena negara bersikap netral bagi semua agama, maka umat Islam pun bisa mengusulkan kebijakan atau perundang-undangan yang bersumber dari agama dengan bersandar kepada apa yang disebut Jhon Rawls sebagai "nalar publik" (public reason): "bahwa alasan, maksud, dan tujuan kebijakan publik atau perundang-undangan harus didasarkan pada pemikiran yang di dalamnya warga pada umumnya bisa menerima atau menolak, dan membuat usulan tandingan melalui debat publik" tanpa harus dihantui ketakutan akan pengafiran dan pemurtadan. ${ }^{28}$

Untuk konteks pengalaman umat Islam Indonesia, ada sebuah semacam fenomena "dikotomi keliru dan dilema yang tak perlu" dalam debat seputar Islam, negara, dan masyarakat di tengah-tengah kaum Muslim. Dikotomi dan dilema yang sebenarnya bisa "dilampaui" jika pilihan yang ditempuh adalah sekularisme dan nalar publik, di mana kaum Muslim Indonesia "tidak harus memilih antara negara Islam yang menerapkan syariah atau negara sekular yang betul-betul menolak syariah."29

Dalam konteks ini juga, maka seorang Muslim boleh membawa agama ke dalam lingkaran politik tetapi pada konteks level political ethics (etika politik). Agama diperlukan untuk membimbing tingkah laku dan moral atau akhlak dalam berpolitik. ${ }^{30}$

Dengan kata lain, yang lebih penting adalah selama suatu negara menjalankan etos islam, kemudian menegakkan keadilan sosial dan menciptakan suatu masyarakat yang egalitarian, yang jauh daripada eksploitasi manusia atas manusia maupun eksploitasi golongan atas golongan yang lain, berarti menurut

\footnotetext{
${ }^{28}$ Abdullah Ahmed al-Naim, Islam dan Negara Sekuler..., h. 22-23.

${ }^{29}$ Abdullah Ahmed al-Naim, Islam dan Negara Sekuler..., h. 437.

${ }^{30}$ Azyumardi Azra, Islam Substantif.., h. 13.
} 
Islam sudah baik. Apalah artinya suatu negara menggunakan Islam sebagai dasar negara, kalau ternyata hanya formalitas kosong?31

Dalam perspektif Indonesia, selama tidak bertentangan dengan ajaran agama Islam, dan semua sila dalam Pancasila itu telah dipraktikkan, itu sudah bagus sekali. Tetapi kalau pancasila juga menjadi semacam formalitas kosong, sebagaimana moralitas Islam menjadi formalitas kosong juga, tentu keadaan demikian harus kita perbaiki bersama. Islam amat menekankan konsistensi antara apa yang diucapkan dengan apa yang dikerjakan.

\section{E. Kesimpulan}

Daya hidup isu dan wacana formalisme syariat dalam konteks Indonesia adalah isu dan wacana yang sia-sia. Hal ini dikarenakan selain isu formalisme syariat itu tidak mempunyai landasan sosio historis, kultural, serta teori yang bernaș, yang perlu dicatat ialah hal ini juga disebabkan organisasi-organisasi besar Islam tidak ada yang tertarik pada gagasan itu. Misalnya Nahdlatul Ulama (NU), Muhammadiyah, Perti, atau Al-Irsyad. Padahal, bisa dikatakan bahwa mereka yang menguasai paling banyak massa Islam yang riil. Kelompok-kelompok yang mempunyai gagasan formalisme syariat itu berada di luar mainstream besar tersebut. Oleh karena itu, pendukung mereka kecil sekali. Tidak signifikan. yang lebih penting adalah selama suatu negara menjalankan etos islam, kemudian menegakkan keadilan sosial dan menciptakan suatu masyarakat yang egalitarian, yang jauh daripada eksploitasi manusia atas manusia maupun eksploitasi golongan atas golongan yang lain, berarti menurut Islam sudah baik. Apalah artinya suatu negara menggunakan Islam sebagai dasar negara, kalau ternyata hanya formalitas kosong?

Dalam perspektif Indonesia, selama tidak bertentangan dengan ajaran agama Islam, dan semua sila dalam Pancasila itu telah dipraktikkan, itu sudah bagus sekali. Tetapi kalau pancasila juga menjadi semacam formalitas kosong, sebagaimana moralitas Islam menjadi formalitas kosong juga, tentu keadaan demikian harus kita perbaiki bersama. Islam amat menekankan konsistensi antara apa yang diucapkan dengan apa yang dikerjakan.

\footnotetext{
${ }^{31}$ Amien Rais, “Tidak Ada Negara Islam”, dalam Ahmad Syafii Maarif, dkk. (ed). Tidak Ada Negara Islam: Surat-surat Politik Nurcholish Madjid-Mohamad Roem, (Jakarta: Djambatan: 2000), h. xxiii.
} 
Berangkat dari itu semua, kita harus membangun dan merumuskan sebuah konsep sistem politik yang mampu mangakomodasi semua kepentingan entitas politik yang secara sosiokultural bersifat heterogen. Tentu sistem politik itu bukan dari hasil adopsi dari nilai-nilai primordialisme tertentu. Jadi, mengapa kita tak bersama-sama berjuang menguatkan demokrasi? Yang oleh Mohammad Hatta dinyatakan sebagai sistem terbaik dan paling manusiawi bagi bangsa Indonesia karena rakyat memiliki hak untuk menentukan nasibnya sendiri. Demokrasi merupakan sistem dan nilai yang menjunjung peradaban tinggi. Sebab, ia melindungi hak-hak dasar manusia atas kehidupan, melindungi mereka yang minoritas, menghargai kemerdekaan dan perbedaan, mendorong musyawarah dan kesepakatan, serta menjunjung kesetaraan dan keadilan. Nilai-nilai demokrasi compatible dengan nilai-nilai Islam. Pilihan atas demokrasi didasarkan atas nilai-nilai di atas yang pada dasarnya "memanusiakan manusia" karena mereka sendiri subjek atas dirinya sendiri. Dalam tata kepemerintahan, rakyat menentukan sendiri apa yang dibutuhkan dalam melaksanakan kehidupan bersama serta menuangkannya dalam kebijakan. Sstem ini ada dalam demokrasi. Tentu, yang saya maksud dengan demokrasi di sini bukanlah demokrasi ala Barat atau Amerika, tetapi demokrasi yang berpijak dan tidak tercerabut dari akar sejarah dan kebudayaan Indonesia sendiri.[w] 


\section{BIBLOGRAFI}

al-Asymawi, Muhammad Said, Shari'a: The Codification of Islamic law". Oxford University Press, 1998.

Azra, Azyumardi, Islam Substantif: Agar Umat Tidak Jadi Buih, Bandung: Mizan, 2000.

Fromm, Erich, The Revolution of Hope: Toward a Humanized Technology, New York: Harper \& Row, 1968.

Hardiman, F. Budi, Demokrasi Deliberatif, Yogyakarta: Kanisius, 2009.

Huntington, Samuel, The Third Wave: Democratization in the Late Twentieth Century, Norman: University of Oklahoma Press, 1991.

Jabiri, al-Abid, “al-'Aqlus Siyāsil ‘Arabī” Vol. III, 1992.

Maarif, Ahmad Syafii, Indonesia di Simpang Jalan, Bandung: Mizan, 1998.

Maarif, Ahmad Syafii, Titik-titik Kisar di Perjalananku: Autobiografi Ahmad Syafii Maarif, Bandung: Mizan, 2009.

Nurcholish Madjid, “Asas-asas Pluralisme dan Toleransi Dalam Masyarakat Madani, dalam Abuddin Nata, dkk. (ed), Problematika Politik Islam di Indonesia, Jakarta: UIN Jakarta Press, 2002.

Mujani, Saiful, "Muslim Demokrat; Islam, Budaya Demokrasi, dan Partisipasi Politik Di Indonesia Pasca Orde Baru”, Jakarta: Gramedia Pustaka Utama, 2007.

Miles, Matthew B. and Huberman A. Michael. Qualitative Data Analysis. Rohidi, Tjejep Rohendi (penerjemah). 2007. Analisis Data Kualitatif: Buku Sumber tentang Metode-metode Baru. UI Press. Jakarta.

Moleong, L.J., Metode Penelitian Kualitatif. Bandung: Remaja Rosdakarya, 2010.

Muhadjir, Neong, Metode Penelitian Kualitatif, Yogyakarta: Rake Sarasin, 1996.

al-Naim, Abdullah Ahmed, Islam dan Negara Sekuler: Menegosiasikan Masa Depan Syariah, Bandung: Mizan, 2007.

Rais, Amien, "Tidak Ada Negara Islam”, dalam Maarif, Ahmad Syafii, dkk (ed). Tidak Ada Negara Islam: Surat-surat Politik Nurcholish Madjid - Mohamad Roem, Jakarta: Djambatan: 2000.

Rahman, Fazlur, Islam. Chicago: University of Chicago Press, 1979. 
Syadzali, Munawir, "Islam dan Tata Negara: Ajaran, Sejarah, dan Pemikiran", Jakarta: UI Press, 1993.

\section{Internet:}

http://id.wikipedia.org/wiki/Agama_di_Indonesia, diakses pada tanggal 20 Maret 2014.

http://www.jpnn.com/read/2014/02/15/216728/318-Kepala-DaerahTerjerat-Korupsi-, diakses pada tanggal 20 Maret 2014.

http://www.republika.co.id/berita/nasional/umum/13/07/22/mqadir-ketikasemangat-otda-diselewengkan-kepala-daerah. Diakses pada tanggal 15 Maret 2014.

Suman, Agus, "Orang Kaya Versus Kemiskinan", http://feb.ub.ac.id/agus-sumanorang-kaya-kemiskinan.html, diakses pada tanggal 16 Maret 2014.

\section{Media Massa:}

Biyanto, "Imajinasi Politik Islam", Jawa Pos, 18 Maret 2014, h. 4.

Jahroni, Jajang, "Khilafah Islam: Khilafah Yang Mana?",Jawa Pos, 16 Mei 2004.

Munir, Lily Zakiyah, "Formalisasi Syariat dan Komitmen Kebangsaan", Jawa Pos, 29 Agustus 2003.

Mawardi, Bandung, “Politik Beretika Publik,” Jawa Pos, 27 Juli 2011.

Muhammad, Husein, "Hukum Tuhan Tetap Perlu Tafsir Manusiawi”, Jawa Pos, 30 Mei 2004.

Sholehuddin, Muhammad, "Desakralisasi Politik Islam”, Jawa Pos, 8 Agustus 2004.

Syam, Nur, "Implementasi Syariat Tanpa Institusi Formal, Jawa Pos, 16 Agustus 2007. 
